present. The Buxton swimming bath at the natural temperature of $82^{\circ} \mathrm{F}$. is one of the most valuable remedies at our disposal. In true neuritis, however, massage is as a rule not beneficial and nerve stretching is quite contraindicated. The combined bath, alternating with the natural swimming bath and the application of electricity in the form of the constant current (5 to 15 milliampères), ascending and descending over the affected nerve, or in the form of the constant current bath, are of much service. The affected limb should be kept warm by the wearing of double-sleeves or double-legged pants of wool. The injection of $\frac{1}{3} \mathrm{gr}$. of pilocarpin nitrate on alternate days for two or three weeks, except in cases where there is organic heart mischief, has been highly praised by Dr. Farqubar of Marlborough.

\section{CASE OF PRECOCIOUS PUBERTy IN A FEMALE CRETIN.}

Bx F. WELLESLEY KENDLE, M.R.C.S. Honorary Secretary of the Barnstaple Division of the British Medical

THE case was exhibited and described before a recent meeting of the Divigion.

B. H., aged 9, is the youngest of seven children. The father is robust, but intemperate; the mother died at 39 , of acute pulmonary phthisis; the mother's sister died at 25 , of acute phthisis; an elder brother, a cretin, lived fifteen years; other brothers, sisters, and relatives healthy. In past generations there has been much intermarrying of near relations on both sides.

The district in which the patient resides is loose shillet and compact limestone, rich in mineral; both parents were reared near a large manganese mine; both cretins were born within a mile of it.

The child showed signs of backwardness about the time she was weaned; the fontanelles remained open. She had no teeth, was unintelligent, and had an unmistakable cretinous appearance. She was treated with freshly-made glycerine extract of sheep's thyroid with marked success for two years. As her mother died when the child was about 3 years old, and she was left in the charge of a sister who was only II treatment became fitful and was gradually discontinued. 1 lost sight of her for six years.

She next came under treatment in April, 1904. I found that not only had she not grown since I last saw her, but that she had retrograded both mentally and physically, until she presented the appearance of a confirmed cretin. Her height was 36 in., weight $47 \mathrm{lb}$., girth 25 in., and chest 26 in. Her expression was dull and vacuous, but she brightened up a little when addressed; she had lack-lustre eyes, short broken lashes, heavy drooping lids, scant eyebrows, wrinkled forehead, depressed bridge of nose, protruding tongue, dribbling mouth, with thick lower lip. She had twelve teeth, all decayed; none had been shed nor had molars been cut. The head was large, the fontanelles and median sutures both depressed. The hair was straight, coarse, dull and brittle, the neck short and fat, the sternum misshapen, the belly full and pendulous, the back hroad, hunched, fat, and covered with silky down; the shoulders rounded, marked lordosis the pelvis tilted, the buttocks ill-developed, the legs short but the bones too thick for their length. The patellae were remarkably small. There was considerable genu valgus, causing the child to walk on the inside of the foot, though there was no true talipes; the gait was jorky and unsteady, with frequent stumbling. She did not play about like othe children, but satstill for hours together, as if hypnotized. She had not been able to learn much, understood and spoke but few words, and uttered these indistinctly in a deep, harsh unchildlike voice. The urine was offensive(phosphatic), and she wetted the bed. The bowels were constipated, and the appetite very capricious; she objected to animal food and sweets, but liked condiments and pickles.

Thus far she presented the appearance of a typical cretin but in one particular she was distinguished from every other recorded case of female cretinism - she was a remarkable example of precocious puberty. The breasts were fully developed, each with a diameter of $3 \frac{1}{3}$ in., with well-shaped, prominent nipples; there was coarse hair in the axillae and pubes. Menstruation commenced at 5 years and 2 months of age, and continued at irregular intervals of from two to four months; the discharge was abundant, quite equal to that of a mature woman, lasting from three to five days, occasionally offensive on the last day, with dysmenorrboea the first day. The urine was particularly offensive during the whole period.

October 26th, 1904. She has now been on thyroid extract for six months, and has made immense progress; she has grown nearly 5 in., and has lost $7 \mathrm{lb}$. in weight; she is much more intelligent, plays, laughs, sings, runs about, and is in constant. mischief. She has cut four double teeth and is shedding her decayed incisors. She no longer wets the bed, and the urine has ceased to be offensive; the bowels are regular and the appetite good. Her expression has so completely changed for the better that she is quite unrecognizable even by her nearest relatives who have not seen her for a few months. The coarse hair has been replaced by a much finer growth that on the back has disappeared; the skin is soft and natural-indeed, the improvement in every respect is most. remarkable.

Strange to say, she has not menstruated since she resumed the thyroid extract; the breasts are much smaller, the nipples less prominent; the hair has disappeared from the axillae and pubes; the voice is less deep, and her whole organism seems to have reverted to a more childlike type. This is the more astonishing, since it is a well-known fact that puberty is invariably delayed in cretins. and that treatment tends to ripen the uterine functions in those cases in which puberty has not run pari passu with adolescence. It almost seems as if the energy of growth initiated by the earlier treatment had become monopolized by the generative organs when the thyroid extract was intermitted, and that on its resumption this has been again diverted for the purposes of bodily and mental growth. So far as I have been able to discover, the case is unique.

January, 1905. Progress still continues; menstruation has not returned. Has grown another 2 in.

\section{MEMORANDA: \\ MEDICAL, SURGICAL, OBSTETRICAL, THERA- peutical, Pathological, Etc.}

\section{SLOUGHING OF INTUASUSCEPTED GUT :} SPONTANEOUS RECOVERY.

ON August 23rd, 1904, I saw a child aged 4 jears, the history of whose case was as follows:

History - On Friday and Saturday, August rgth and zoth, the child had suffered with what appeared to be an ordinary attack of diarrhoea attended with slight vomiting. On the evening of the soth it for the first time passed a little blood per rectum. After this the child passed at intervals small quantities of blood and mucus per rectum but, the mother expressed it, the diarrhoea stopped, but the child vomited everything it took by the mouth. This condition lasted untll the time of my visit on August 23 rd.

State on Examination. - The child was looking extremely pinched and ill, the pulse small and very rapid, the eyes hollow and sunken, and the mouth almost dry. The abdomen was very much distended and highly tympanitic. The outline of the coils of the small intestine were most markedly visible on inspection. The napkins which the child had worn were all stained with blood and mucus. There was nothing to be felt on rectal examination. In the upper part of the right iliac region I could detect slight resistance on palpation, but no definite sausageshaped tumour.

Treatment - I diagnosed ileo-caecal intussusception, and decided to try injection of the colon with warm water. IVith a stomach-tube passed well into the rectum $I$ poured in about three pints of warm water, having the child practically inverted and allowing about $3 \mathrm{ft}$. of pressure on the water. This manceuvre seemed to cause the child some pain. After retaining the child for about ten minutes in the inverted position, I allowed the water to b ratured portion to be.expelled was bloodstained and extremely evil-smelling, having exactly the aroma of gangrenous tissue.

Progress - On my visit some two hours later I found that the symptoms of obstruction were still entirely unrelieved, so I asked my friend Dr. Mathews to see the case with me. We decided that in the child's bad condition an abdominal section would probably be fatal in its result, and that, seeing that the gut was probably gangrenous, and that further attempts at reduction by injection would be almost equally dangerous, the only thing to do was to make the child as comfortable as possible, and to hope that Nature might effect a cure. I accordingly ordered the child r-minim doses of liq. morph. hydrochlor., to be given every hour until sleep was obtained.

Result.-During the next day, August 24th, the patient's condition was very grave; the vomiting was persistent and the distension very pronounced; nothing whatever had passed per rectum. On the morning of the $25^{\text {th }}$ the condition was still the same, and I thought the child's end was near. In the evening of the 25 th I again saw the patient, when I was 